\title{
COMPARISON OF THE FLUORESCENT TREPONEMAL ANTIBODY TEST WITH OTHER TESTS FOR SYPHILIS ON CEREBROSPINAL FLUIDS* ${ }^{*}$
}

\author{
BY \\ AD HARRIS, $\ddagger$ H. M. BOSSAK, $\ddagger$ W. E. DEACON, $\ddagger$ AND W. L. BUNCH, JR. $\S$ \\ Chamblee, Ga., and Raleigh, N.C., U.S.A.
}

Tests for syphilis on cerebrospinal fluids were evaluated in the Washington, D.C., Serology Conference of 1941 (J. vener. Dis. Inform., 1942), but spinal fluids were omitted from the later Serology Evaluation and Research Assembly Study in 1956-57 (S.E.R.A., 1959). Since this earlier evaluation, several treponemal antigen tests have been described. The Treponema pallidum immobilization (TPI), fluorescent treponemal antibody (FTA), and Kolmer complement-fixation tests using Reiter protein antigen (KRP) are three tests designed to detect antibodies differing from those that caused reactivity in the non-treponemal antigen tests. The FTA test has been used for testing sera, but has not properly been evaluated as a spinal fluid test. This study was conducted to evaluate the FTA test in comparison with other treponemal tests for syphilis on spinal fluids. The VDRL spinal fluid test was included in this study to offer a comparison of the non-treponemal with the treponemal test results.

\section{Methods}

Spinal Fluids.-These were obtained from 59 unselected patients undergoing surgical operations and were withdrawn before the administration of spinal anaesthesia. Other spinal fluid specimens were obtained from 369 clinic patients, all of whom had received penicillin treatment for syphilis before this examination.

The four tests (TPI, FTA, KRP, and VDRL) were performed as described in the Manual of Serologic Tests for Syphilis (1959 revision) with the exception that the FTA test was amended to eliminate weakly reactive

* Presented in part at the Eleventh Annual Symposium on Recent Advances in the Study of Venereal Diseases, April 7-8, 1960, Chicago, Illinois.

† Received for publication April 20, 1960.

$\ddagger$ Mr. Harris is Director, Mr. Bossak is Chief, Training and Testing Services, and Dr. Deacon is Chief, Microbiology Unit, of the Venereal Disease Research Laboratory, Venereal Disease Branch, Communicable Disease Center, P.H.S., Chamblee, Georgia.

$\S$ Dr. Bunch was Venereal Disease Control Officer, Fulton County Health Department, Atlanta, Georgia, and is now Chief, Venereal Disease Control Section, North Carolina State Board of Health, Raleigh, North Carolina. reports (Deacon, Freeman, and Harris, 1960), and the spinal fluids were tested at the dilutions noted below (Table II). In the TPI test, $0.05 \mathrm{ml}$. spinal fluid was tested.

\section{Results}

As shown in Table I, the FTA test was much more reactive than the other tests performed. Reactivities (Reactive + Weakly Reactive) ranged from 19.6 per cent FTA test, $6 \cdot 2$ per cent. TPI test, $3 \cdot 8$ per cent. VDRL test, to 2.9 per cent. for the KRP test. Table II shows that all four tests were in agreement on 350 (82 per cent.) of the spinal fluids tested, 344 being non-reactive in all tests, and only six being reactive or weakly reactive, with other tests nonreactive. Reactivity in either the KRP or VDRL tests was always accompanied by reactivity in one or more of the other tests. 52 spinal fluids reacted in the FTA test only.

TABLE I

COMPARATIVE TEST REACTIVITIES

\begin{tabular}{lll|c|c|c|c}
\hline & Test & & Reactive & $\begin{array}{c}\text { Weakly } \\
\text { Reactive }\end{array}$ & $\begin{array}{c}\text { Non- } \\
\text { Reactive }\end{array}$ & Total \\
\hline FTA &.. &.. & 82 & 0 & 346 & 428 \\
\hline TPI &.. &.. & 18 & 8 & 402 & 428 \\
\hline KRP &.. &.. & 12 & 0 & 416 & 428 \\
\hline VDRL &.. &.. & 16 & 0 & 412 & 428 \\
\hline
\end{tabular}

Titres of eighty FTA reactive fluids from syphilitic patients (Table II, opposite) ranged from undiluted or dilution 1:1 to dilution 1:640 (Mode 1:1, Median 1:10, Mean 1:35). A higher than average range of FTA titres was noted in the six fluids that were reactive in all four tests, ranging from 1:40 to 1:640, and the largest number of lower titres in this test (1:1 to $1: 40$ ) was obtained when only the FTA test was reactive. The two specimens that reacted in all tests except the TPI test had FTA test titres of $1: 80$ and $1: 320$ respectively. 
TABLE II

RESULTS

\begin{tabular}{|c|c|c|c|c|c|c|c|c|c|c|c|c|c|c|}
\hline \multirow{2}{*}{ Patients } & \multicolumn{4}{|c|}{ Tests for Syphilis } & \multicolumn{9}{|c|}{ FTA Titres } & \multirow{2}{*}{ Totals } \\
\hline & FTA & TPI & KRP & VDRL & $1: 1$ & $1: 5$ & $1: 10$ & $1: 20$ & $1: 40$ & $1: 80$ & $1: 160$ & $1: 320$ & $1: 640$ & \\
\hline \multirow{14}{*}{ Syphilis Clinic } & $\mathbf{N}$ & $\mathbf{N}$ & $\mathbf{N}$ & $\mathbf{N}$ & & & & & & & & & & 287 \\
\hline & $\mathbf{N}$ & $\mathbf{R}$ & $\mathbf{N}$ & $\mathbf{N}$ & & & & & & & & & & 1 \\
\hline & $\mathbf{N}$ & WR & $\mathbf{N}$ & $\mathbf{N}$ & & & & & & & & & & 1 \\
\hline & $\mathbf{R}$ & $\mathbf{R}$ & $\mathbf{R}$ & $\mathbf{R}$ & & & & & 1 & 2 & 1 & 1 & 1 & 6 \\
\hline & $\mathbf{R}$ & $\mathbf{R}$ & $\mathbf{R}$ & $\mathbf{N}$ & & & & & 1 & 1 & & & & 2 \\
\hline & $\mathbf{R}$ & $\mathbf{R}$ & $\mathbf{N}$ & $\mathbf{R}$ & & & & 1 & 2 & & & & & 3 \\
\hline & $\mathbf{R}$ & $\mathbf{R}$ & $\mathbf{N}$ & $\mathbf{N}$ & & & 1 & 2 & 2 & 1 & & & & 6 \\
\hline & $\mathbf{R}$ & WR & $\mathbf{R}$ & $\mathbf{R}$ & & & & 1 & & & & & & 1 \\
\hline & $\mathbf{R}$ & WR & $\mathbf{R}$ & $\mathbf{N}$ & & 1 & & & & & & & & 1 \\
\hline & $\mathbf{R}$ & WR & $\mathbf{N}$ & $\mathbf{N}$ & 1 & 1 & & 3 & & & & & & 5 \\
\hline & $\mathbf{R}$ & $\mathbf{N}$ & $\mathbf{R}$ & $\mathbf{R}$ & & & & & & 1 & & 1 & & 2 \\
\hline & $\mathbf{R}$ & $\mathbf{N}$ & $\mathbf{N}$ & $\mathbf{R}$ & & & & 2 & 2 & & & & & 4 \\
\hline & $\mathbf{R}$ & $\mathbf{N}$ & $\mathbf{N}$ & $\mathbf{N}$ & 19 & 14 & 7 & 6 & 4 & & & & & 50 \\
\hline & \multicolumn{2}{|c|}{ Totals } & .. & . & 20 & 16 & 8 & 15 & 12 & 5 & 1 & 2 & 1 & 369 \\
\hline \multirow{3}{*}{ Pre-Anaesthesia } & $\mathbf{R}$ & $\mathbf{N}$ & $\mathbf{N}$ & $\mathbf{N}$ & $1^{*}$ & & $1 t$ & & & & & & & 2 \\
\hline & $\mathbf{N}$ & $\mathbf{N}$ & $\mathbf{N}$ & $\mathbf{N}$ & & & & & & & & & & 57 \\
\hline & \multicolumn{2}{|l|}{ Totals } & . & .. & 1 & & 1 & & & & & & & 59 \\
\hline Grand Totals & .. & . & .. & $\ldots$ & 21 & 16 & 9 & 15 & 12 & 5 & 1 & 2 & 1 & 428 \\
\hline
\end{tabular}

* 61-year-old male. Diabetes, gangrene of foot, osteomyelitis (blood tests for syphilis repeatedly reactive).

† 73-year-old male. Adenocarcinoma of prostate, luetic aortic insufficiency (later verified by post-morem findings).

$\mathbf{R}=$ Reactive; $\mathbf{W R}=$ Weakly Reactive; $\mathbf{N}=$ Non-reactive.

\section{Discussion}

Absolute agreement was not obtained between results of any two of the four tests, and there was as much disagreement amongst the three treponemal tests as there was between the treponemal and nontreponemal test results (Table II). These differences, although reflecting the ability of the tests to detect different antibodies, may also reflect differing testreactivity levels.

The FTA test was finally designed to test sera at dilution 1:200. The FTA test with undiluted spinal fluid uses this body fluid at approximately the same protein concentration as serum diluted $200 \times$, but the amount of reactive component (globulin) in the spinal fluid may be greater when the albuminglobulin ratio is abnormal. It therefore appears that at the FTA test with either undiluted spinal fluid or serum diluted $200 \times$ will be set at approximately the same detection levels.

The value of detecting treponemal antibodies in spinal fluids is not clearly understood at this time. More study will be needed to ascertain whether their presence indicates actively destructive or invasive luetic processes, past or present, in the central nervous system areas, or merely immune tissue responses.

The FTA test is a new and sensitive procedure that may be used to detect small amounts of treponemal antibody in spinal fluids. If the FTA, TPI, and KRP tests are capable of detecting a common antibody in spinal fluids, the FTA test is evidently the most sensitive of these three procedures. The two fluids from the pre-anaesthesia patients that reacted only to the FTA test came from subjects who could have been classed as syphilitic, although this diagnosis was recorded for only one of them. There is no evidence in this study that the use of undiluted spinal fluid in the FTA test would cause this procedure to be reactive with spinal fluids from clearly defined non-syphilitic patients.

The FTA test was the most reactive and the KRP test the least reactive of the treponemal tests. The TPI test had a reactivity level between the other two treponemal tests, but agreed more frequently with

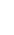


the KRP test ( 410 of $428 ; 96$ per cent.) than with the FTA test (368 of $428 ; 86$ per cent.). The reactivity pattern of the VDRL spinal fluid test did not indicate a close relationship to any of the treponemal tests, but the number of reactive results with this procedure was closest to that with the KRP test. This is no indication, however, that similar antibodies were detected by these two tests.

Actual amounts of spinal fluids tested in the four procedures were: FTA $=0.03 \mathrm{ml}$., TPI $=0.05 \mathrm{ml}$., $\mathrm{KRP}=0.1 \mathrm{ml}$, and VDRL $=1.0 \mathrm{ml}$. Among the treponemal tests, the test reactivity levels were in reverse order to the amounts of fluid tested, the most reactive test (FTA) using the smallest amount of spinal fluid. It therefore appears that the measurement of antigen-antibody reactivity by fluorescence (FTA) is more sensitive than by immobilization or direct complement-fixation as used in the TPI and KRP tests.

\section{Summary}

The FTA test was compared with the TPI, KRP, and VDRL tests in spinal fluids from 369 syphilis clinic patients and 59 pre-anaesthesia patients. The results obtained with these four tests are presented and discussed.
REFERENCES

Deacon, W. E., Freeman, E. M., and Harris, A. (1960). Proc. Soc. exp. Biol. (N.Y.), 103, 827

"Serologic Tests for Syphilis, 1959 Manual." (1959 revision). U.S Department of Health, Education, and Welfare, Public Health Service, Bureau of State Services, Communicable Disease Center. U.S. Government Printing Office, Washington 25, D.C

"Serology Evaluation and Research Assembly 1956-1957," (1959) PHS Publication No. 650, U.S. Department of Health, Education, and Welfare, Public Health Service, Bureau of State Services, Communicable Disease Center. U.S. Government Printing Office, Washington 25, D.C.

Washington Serology Conference Preliminary Report (1942). J. vener. Dis. Inform., 23, 161.

Comparaison entre la réaction de l'anticorps tréponémique fluorescent et d'autres réactions pour la syphilis dans le liquide céphalo-rachidien

Résumé

On a comparé les résultats obtenus avec la réaction FTA (fluorescent treponemal antibody $=$ trad. lit. "anticorps tréponémique fluorescent") à ceux obtenus avec d'autres réactions: TPI (d'immobilisation du T. pallidum), KRP (de Kolmer, de fixation du complément, avec emploi de l'antigène de Reiter) et VDRL (Venereal Disease Reference Laboratory - réaction standard américaine). Toutes ces réactions furent effectuées sur des échantillons de liquide céphalo-rachidien obtenus de 369 malades syphilitiques et de 69 malades chirurgicaux non-syphilitiques. Les auteurs concluent que la réaction FTA semble être plus sensible pour rechercher la syphilis dans le liquide céphalo-rachidien que les réactions spécifiques TPI et KRP et la non spécifique VDRL. 